\title{
Histamine combined with melphalan in isolated limb perfusion for the treatment of locally advanced soft tissue sarcomas: preclinical studies in rats ${ }^{1}$
}

\author{
Histamina combinada ao melfalano na perfusão de membro isolado para o tratamento \\ de sarcomas de partes moles localmente avançado: estudos pré-clínicos em ratos ${ }^{1}$
}

\author{
Flavia Brunstein ${ }^{2}$, Ivan Dunshee de Abranches Oliveira Santos ${ }^{3}$, Lydia Masako Ferreira ${ }^{4}$, Sandra T. van Tiel ${ }^{5}$, Alexander \\ M. M. Eggermont ${ }^{6}$, Timo L. M. Ten Hagen ${ }^{7}$
}

1. Laboratory of Experimental Surgical Oncology - Daniel den Hoed Cancer Center - Erasmus MC - Rotterdam - the Netherlands.

2. Plastic Surgery Department - Federal University of Sao Paulo (UNIFESP)-Brazil.

3. Associate Professor and Head of the Tumors Division-Plastic Surgery Department - UNIFESP

4. Head of the Plastic Surgery Department - UNIFESP

5. Technician - Laboratory of Experimental Surgery - Surgical Oncology Department - Erasmus MC, Daniel den Hoed Cancer Center Rotterdam - the Netherlands

6. Head of the Surgical Oncology Department - Erasmus MC - Daniel den Hoed Cancer Center - Rotterdam - the Netherlands

7. Head of the Laboratory of Experimental Surgical Oncology - Surgical Oncology Department - Erasmus MC - Daniel den Hoed Cancer Center - Rotterdam - the Netherlands

\begin{abstract}
Purpose: To evaluate the potential benefit of histamine combined with melphalan in the isolated limb perfusion (ILP) as an alternative to TNF-alfa and melphalan combination, for the treatment of irressectable soft tissue sarcomas of the limbs in Brown Norway (BN) rats. Methods: 20 BN rats had small fragments of syngeneic BN-175 fibosarcoma inserted on the right hind limb. In 7-10 days the tumor reached a median diameter of 12-15 mm and they were randomly divided in four groups (sham, melphalan, histamine and escalating doses of histamine combined to melphalan) being submitted to experimental ILP for 30 minutes. Tumors were measured daily with a caliper and the volume was calculated. Results: Response curves showed a significant effect of the combination of histamine $200 \mathrm{mg} / \mathrm{mL}$ with melphalan, with $66 \%$ overall response, including 33\% complete responses $(\mathrm{p}<0.01)$. There were no systemic collateral effects and locally only mild temporary edema was observed for some animals treated with histamine. Conclusion: Histamine combined with melphalan had a promising effect in the ILP warranting future studies to better explore the mechanism of action as well as its potential use in organ perfusion.
\end{abstract}

Key words: Sarcomas. Experimental models. Regional treatment. Histamine.

\section{RESUMO}

Objetivo: Avaliar o potencial benéfico da histamina combinada ao melfalano, na perfusão de membro isolado (PMI), como alternativa à combinação TNF-alfa mais melfalano, no tratamento de sarcomas de partes moles irressecaveis em extremidades, em ratos de linhagem Brown Norway (BN). Métodos: 20 ratos BN foram submetidos a implantação de fragmentos de fibrosarcoma singênico BN-175 na pata traseira direita. Em cerca de 7-10 dias o tumor atingiu um diâmetro médio de 12-15 mm e foram aleatóriamente divididos em quatro grupos (controle, melfalano, histamina em doses progessivas combinada ao melfalano e histamina) sendo submetidos a PMI experimental por 30 minutos. Os tumores foram então medidos diariamente com o uso de paquímetro e o volume tumoral calculado. Resultados: As curvas de resposta mostram um efeito significativo da combinação de Histamina na concentração de $200 \mathrm{mg} / \mathrm{mL}$ ao melfalano, com 66\% de resposta global incluindo 33\% de respostas completas $(\mathrm{p}<0.01)$. Não houve efeitos colaterais sistêmicos e localmente apenas edema leve e transitório nos animais tratados com histamine. Conclusão: A histamina em combinação com o melfalano apresenta um efeito promissor na PMI garantindo maiores investigações do seu mecanismo de ação e do seu potencial uso na perfusão de órgãos.

Descritores: Sarcomas. Modelos experimentais. Tratamento regional. Histamina

\section{Introduction}

Soft tissue sarcomas (STS) are tumors of mesenchymal origin and account for approximately $1 \%$ of all adult malignant tumors in the USA ${ }^{1}$ and for 5,500 new cases per year in Brazil. Circa 60\% of them occur in the extremities and are often large at first diagnosis with an aggressive local growth and propensity for hematogenic spread so that half of the patients will die of disseminated disease. Limb amputation has not shown any benefit in overall survival, thus conservative approaches capable of preserving extremities and maintaining good function are a corner stone of patient approach ${ }^{2}$. Isolated limb perfusion (ILP) was first described as a treatment modality for in transit metastasis 
of melanoma restricted to the limbs, based on the delivery of high doses of cytostatic drugs (mainly melphalan for the best results and least morbidity) to a tumor-bearing extremity, surgically and temporarily isolated from the systemic circulation by the use of a heart-lung machine ${ }^{3,4,5}$. The rational of the method is that in the ILP setting locoregional concentrations of melphalan, 15 to 20 times higher than after systemic administration, can be achieved without systemic toxicity ${ }^{6,7}$. Complete responses (CR) reached up to $50 \%{ }^{8}$ in melanoma patients while in soft tissue sarcomas responses were as poor as $20 \%$ Overall Responses (OR), including partial and complete ${ }^{9}$. The combination of TNF-alpha to melphalan brought a new perspective to this modality of treatment with a limb salvage index of $71 \%$ and $76 \%$ of OR ${ }^{6}$. In spite of these excellent results, circa $30 \%$ of the patients will not respond to standard treatment and might require a limb amputation. Furthermore, TNF-alpha is still not available in many countries both for regulatory and economic reasons restricting the use of this limb salvage procedure to the treatment of in transit metastasis of melanoma. This is still the situation in Brazil, for example, in spite of an experience of more than 10 years with ILP ${ }^{5}$. Searching for an alternative we evaluated the potential benefit of Histamine (Hi), an inflammatory mediator formed and stored mainly in the granules of mast cells and basophils but also in cells of the epidermis, gastric mucosa, and neurons of the central nervous system as well as in cells in regenerating or rapidly growing tissues. Its classical effect on fine vessels is the formation of edema by an increase in the flow of lymph and its protein content to the extracellular space and also the formation of gaps between endothelial cells, increasing transcapillary vesicular transport ${ }^{10}$. Potentially, this could result in an enhanced drug uptake in the tumor and thus lead to improved antitumor responses. We used an established experimental model ${ }^{11}$, which closely mimics the clinical ILP, in order to evaluate the potential synergy of $\mathrm{Hi}$ with melphalan, improving tumor response in soft tissue sarcomas.

\section{Methods}

The studies were done at the Laboratory for Experimental Surgical Oncology of the Department of Surgical Oncology of the Erasmus University Medical Center in Rotterdam, the Netherlands. They were in accordance with the Dutch Animal Experimentation Act (1977) and the Guidelines on the protection of experimental animals of the European Community council (1986). Furthermore, the specific protocols for this study were approved by the Erasmus University Rotterdam Animal Committee - the Netherlands. Male inbred Brown Norway (BN) rats were obtained from Harlan-CPB (Austerlitz, the Netherlands), weighing 250-300 g and were fed a standard laboratory diet ad libitum (Hope Farms Woerden, the Netherlands). Frozen small fragments ( $3 \mathrm{~mm}$ ) of the syngeneic BN-175 sarcoma maintained in liquid nitrogen under $-80^{\circ} \mathrm{C}$ were quickly defrost and inserted subcutaneously in the dorsum of BN rats for expansion. Upon a diameter of around $3 \mathrm{~cm}$ the animal was killed under anesthesia by cervical dislocation and the tumor excised and then divided in small fragments of viable tumor tissue of circa $3 \mathrm{~mm}$ diameter. Next, these small fragments were inserted subcutaneously in the right hind leg of the animals in groups no bigger than 15 animals. For this, a little incision on the skin above the ankle was made, with the dissection of the tissue and its closure with clip $^{12}$. Tumor growth was evaluated by daily measures of the main diameters with a caliper and the calculation of the volume using the formula $0.4\left(\mathrm{~A}^{2} \mathrm{x} \mathrm{B}\right)$ (where $\mathrm{B}$ represents the largest tumor diameter and $A$ is the diameter perpendicular to it). When tumor diameter exceeded $25 \mathrm{~mm}$ or at the end of the experiment rats were killed by cervical dislocation, under anesthesia. In seven to ten days, the diameter reached values between $12-15 \mathrm{~mm}$ and the tumors were amenable to the procedure ${ }^{12}$ (Figure 1a). Under anesthesia, using $0.5 \mathrm{ig} / \mathrm{kg}$ intraperitoneal ketamine and 0.5 ìg/kg intramuscular hypnomidate, the rats were fixed in dorsal position to the operating table with adhesive tape. The inguinal vessels (Figure $1 \mathrm{~b}$ ) were reached through an incision parallel to the inguinal ligament with the use of a surgical microscope. Before manipulating the vessels, 50 IU of heparin were administered in bolus by the penile vein. Next, the femoral artery and vein were canulated with silicon tubes measuring 0.012 inches internal diameter and 0.025 of external diameter and 0.025 and 0.047 inches, respectively (Dow Corning, Michigan, USA). The tubes were connected via a roller pump to an oxygenated reservoir containing 5 $\mathrm{mL}$ perfusate. A groin tourniquet occluded collateral vessels, warranting a proper isolation of the limb, controlled by the maintenance of a stable volume (Figures 1c and d).

The limb was maintained at a temperature of $38^{\circ} \mathrm{C}$ by the use of a water mattress around the limb covered by an aluminum foil. A thermometer controlled the temperature during the whole procedure that lasted 30 minutes. At the end of the ILP a washout was done with $2 \mathrm{~mL}$ of oxygenated haemaccel. Next the cannulas were taken out and the vessels ligated. Skin was closed with continuous suture and the animal was put under a heating light till complete recovery, in order to avoid hypothermia. According to the group the animal was randomized to, the $5 \mathrm{~mL}$ perfusate would consist of: 1) haemaccel alone (Boehring Pharma, Amsterdam, the Netherlands); 2) haemaccel plus $40 \mathrm{mg}$ melphalan (AlkeranÒ Wellcome, Beckenham, United Kingdom); 3) haemaccel, 40 mg melphalan and escalating doses of Hi (kindly provided by Maxim Pharmaceuticals Inc., San Diego, CA), ranging from 100 to $2000 \mathrm{mg}$ or 4) haemaccel plus $1000 \mathrm{mg}$ Hi. Tumor dimensions were measured every day for volume evaluation. Response was classified as: progressive disease (PD) increase of more than 25\%; no change (NC) volume kept in the range of $-25 \%$ to $+25 \%$ of the initial one; partial remission (PR) decrease between $-25 \%$ and $-90 \%$, or complete response (CR) final tumor volume less than $10 \%$ of initial, as compared to volume on day nine. Limb function was clinically observed as the ability to walk and stand on the perfused limb after ILP. On a scale from grade 0 to 2, grade 0 is a severely impaired function where the rat drags its hind limb; 1, a slightly impaired function (can not use it in a normal way, but stand on it); finally 2 is an intact function (normal walking and standing pattern). Tumor growth curves were plotted as means and standard deviation (SD) of the data from all animals. Statistical evaluation was done by repeated measures ANOVA analyses of the three most 
representative days: 4, 8 and 10 using SAS Software Release 8.2 for Windows 2000 (SAS Institute Inc., Cary, NC, USA) using PROC MIXED. Main effects of treatment and day (three levels: day 4, 8 and 10) were included in the models as was the interaction between treatment and day. For days where response was statistically significant, interaction terms were further investigated by testing for differences following treatment on that day.
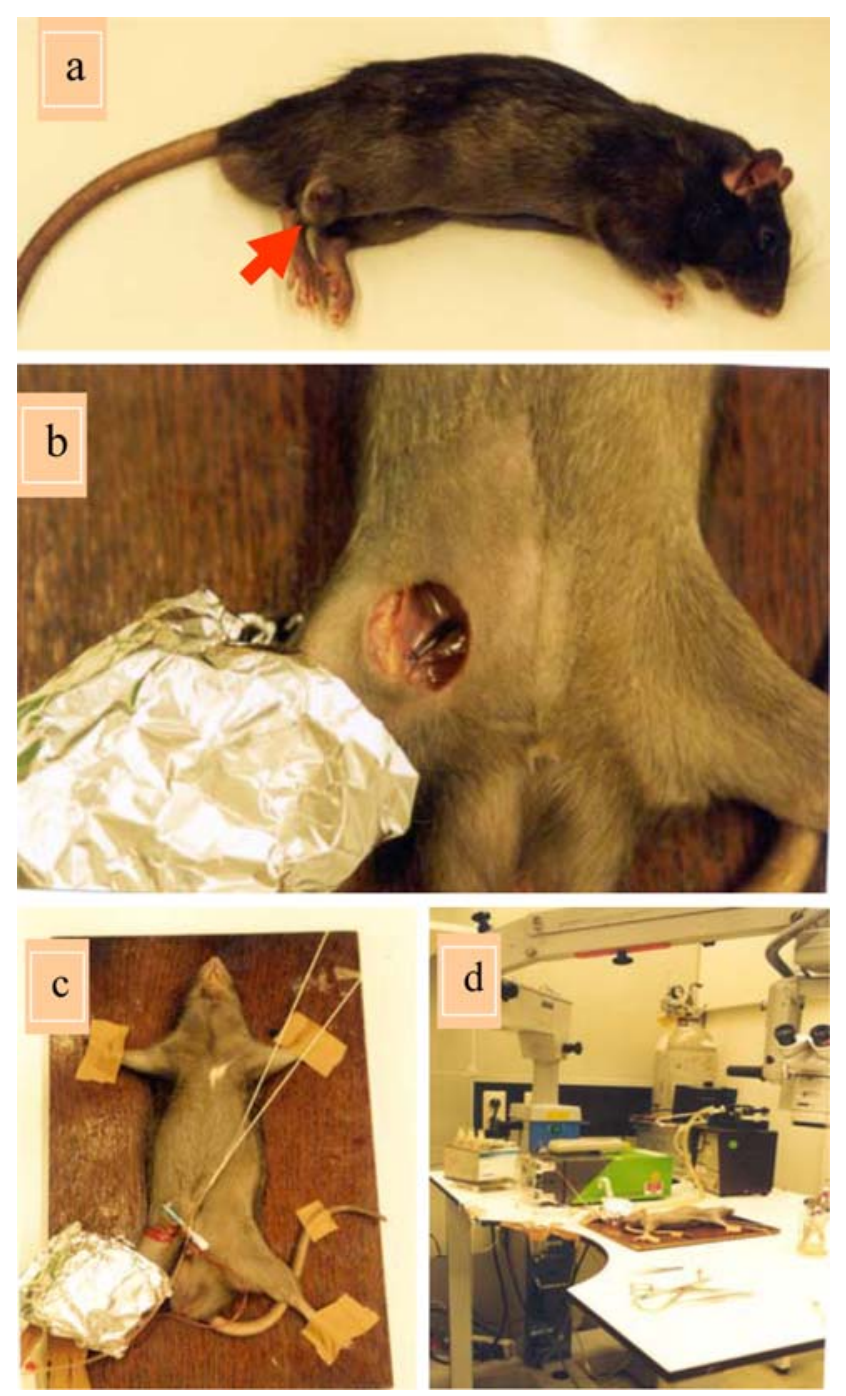

FIGURE 1 - a) Brown Norway (BN) rat showing the tumor amenable to experimental ILP (red arrow); b) close up view of the inguinal incision showing the femoral artery and vein; c) eye-bird view of the experimental ILP showing the dorsal position of the animal, fixed with adhesive tapes to the operating table and the cotton swab combined to a rubber band, used as a tourniquet; d) wider view of the surgical table with the operating microscope, the pumping machine (green) and the heater (brown).

\section{Results}

Tumors grew exponentially in the BN rats after control ILP, as expected. The use of Hi plus melphalan led to tumor regression in $66 \%$ of the treated animals, including $33 \%$ with no palpable tumors (CR), approximately 10 days after treatment $(\mathrm{p}<0.01)$ (Fig 2 and 3 ). This effect was only observed when Hi dose reached 1,000 mg (concentration of $200 \mathrm{mg} / \mathrm{mL}$ ) and would not improve even after doubling the concentration to $400 \mathrm{mg} / \mathrm{mL}$. It is also of note that Hi alone had an effect very similar to melphalan alone, when the curves are evaluated together (Fig 3). Yet, looking closer at the pattern of response the first resulted in a reduced or stable tumor growth rate with 50\% SD while the second led to $17 \%$ PR. Perfusion with Hi, either alone or combined with melphalan, did not cause systemic side effects. As for regional toxicity only some transient edema after Hi ILP, both with and without melphalan, was observed leading to temporary grade 1 toxicity in two rats for each group.

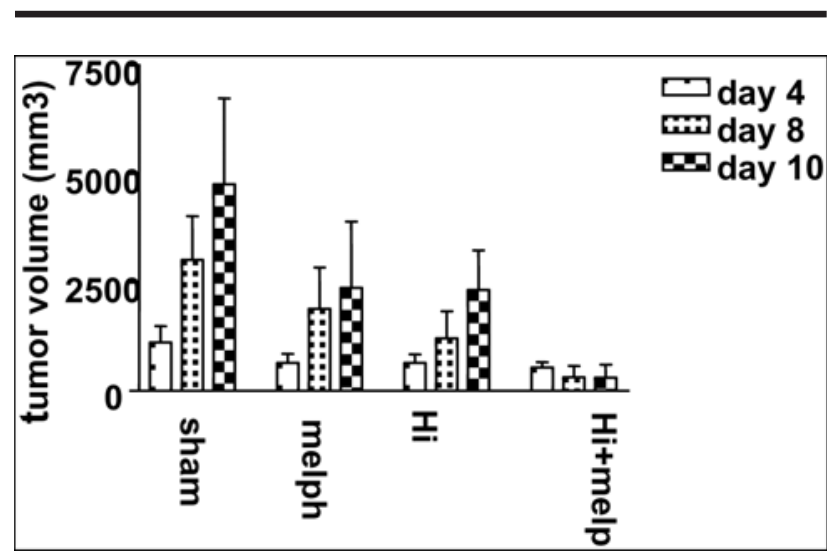

FIGURE 2 - Tumor volume on days 4, 8 and 10 according to the ILP treatment administered. Tumors were measured daily with a caliper and volume was calculated using the formula 0.4 (A2 $\mathrm{x}$ $\mathrm{B})$ (where $\mathrm{B}$ represents the largest tumor diameter and $\mathrm{A}$ is the diameter perpendicular to it).

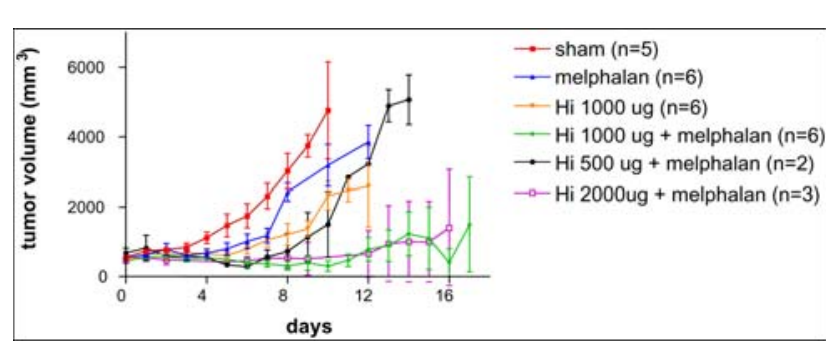

FIGURE 3 - Tumor response after experimental ILP with Sham, Hi 1000 ug, Hi 500, 1000 and 2000 ug combined to melphalan. Mean tumor volumes with standard deviation. $\mathrm{P}<0.01$ for Hi $1000 \mathrm{ug}+$ melphalan on day 8 and 10 as compared to Sham. 


\section{Discussion}

First of all is important to stress that the experimental model of ILP requires a learning curve before obtaining trustable results. One of the main issues playing a role on quality is the time taken between anesthesia and the isolation and canulation of the femoral vessels. This might determine a significant leakage and, in this case just opposite to what is seen in the clinical setting there is not much to do besides reducing flow speed. Once more than $4 \mathrm{~mL}$ is lost the limb will present such a significant edema in the post-operative period that further evaluation of the treatment administered is prevented. Also the morbidity in these situations would result in such a suffering of the subject that, according to ethical recommendations, it would be better to sacrifice the animal. We showed for the first time the promising activity of Histamine plus melphalan in ILP, for the treatment of soft tissue sarcomas. Among the advantages of $\mathrm{Hi}$ as compared to TNF-alpha we could include its pharmacokinetics with a short half-life in the serum of only 0.35 minutes against 20 minutes for TNF-a ${ }^{13}$. Hi is metabolized through two major pathways in man: the more important involves ring methylation and is catalyzed by the enzyme histamine-Nmethyltransferase, which is widely distributed. Most of the product, $\mathrm{N}$-methylhistamine is converted by monoamine oxidase (MAO) to N-methyl imidazole acetic acid.

Alternatively $\mathrm{Hi}$ undergoes oxidative deamination catalyzed mainly by the nonspecific enzyme diamine oxidase (DAO). The products are imidazole acetic acid and its riboside. The metabolites with little or no activity are excreted in the urine ${ }^{10}$. Although these data come from studies with lower dosages or endogenous Hi they describe a widely distributed and fast metabolizing system, which would suggest a potentially safer drug in case of some leakage during the ILP. Furthermore, our finding opens new possibilities of application in potentially less well-isolated settings as for example the isolated liver perfusion. Still, more studies on the pharmacokinetics for the higher doses and evaluation in the clinical setting are mandatory for the clinical translation of $\mathrm{Hi}$.

Another advantage, mainly for exploring its use in organ perfusion, would be its lack of toxicity towards the liver as compared to TNF-a, which exhibits a small window for dosage increase.

\section{Conclusion}

Hi plus melphalan in the ILP seems a promising alternative and worth being evaluated in the clinical setting. Further studies are required to better detail its mechanism of action.

\section{References}

1. Wingo PA, Tong T, Bolden S. Cancer statistics, 1995. CA Cancer J Clin. 1995; 45(1):8-30

2. Eggermont AM, ten Hagen TL. Isolated limb perfusion for extremity soft-tissue sarcomas, in-transit metastases, and other unresectable tumors: credits, debits, and future perspectives. Curr Oncol Rep. 2001;3(4):359-67.

3. Chreech Jr. O, Krementz ET, Ryan RF, Winblad JN. Chemotherapy of cancer: Regional perfusion using an Extracorporeal circuit. Ann Surg. 1958; 148: 616-32.

4. van Etten B, van Geel AN, de Wilt JH, Eggermont AM. Fifty tumor necrosis factor-based isolated limb perfusions for limb salvage in patients older than 75 years with limbthreatening soft tissue sarcomas and other extremity tumors. Ann Surg Oncol. 2003;10(1):32-7

5. Brunstein F, Santos IDAO, Gomes WJ, de Carvalho LMY, de Lima AH, Belfort FA, Ferreira LM. O uso da perfusão hipertérmica de membro isolado no tratamento das metástases em transito de melanoma. Rev Soc Bras Cancerol. 2002; 17: 14-8

6. Eggermont AM, Schraffordt KH, Klausner JM, Kroon BB, Schlag, PM, Lienard D, Van Geel AN, Hoekstra HJ, Lejeune FJ. Isolated limb perfusion with tumor necrosis factor and melphalan for limb salvage in 186 patients with locally advanced soft tissue extremity sarcomas. The cumulative multicenter European experience. Ann Surg. 1996; 224:756-64.

7. Eggermont AM, de Wilt JH, ten Hagen TL. Current uses of isolated limb perfusion in the clinic and a model system for new strategies. Lancet Oncol. 2003; 4:429-37.

8. Lienard D, Ewalenko P, Delmonte JJ, Renard N, Lejeune FJ. High dose recombinant tumor necrosis factor alpha in combination with interferon-gamma and melphalan in isolation perfusion of the limbs for melanoma and sarcoma. J Clin Oncol. 1992; 10: 52-60.

9. Hoekstra HJ, Schraffordt-Koops H, Molenaar WM, Oldhoff J. Resulsts of isolated regional perfusion in the treatment of malignant soft tissue tumors of the extremities. Cancer. 1987; 60: 1703-7.

10. Garrison JC. Histamine, Bradykinin, 5-Hydroxytryptamine and their antagonists: In: Gilman AG, Rall TW, Nie AST. 8ed. Elmsford/New York: 1990. p. 575-99.

11. Manusama ER, Stavast J, Durante NM, Marquet RL, Eggermont AM. Isolated limb perfusion with TNF alpha and melphalan in a rat osteosarcoma model: a new antitumor approach. Eur. J Surg Oncol. 1996; 22: 152-7.

12. de Wilt JH, ten Hagen TL, de Boeck G, van Tiel ST, de Bruijn EA, Eggermont AMM. Tumor necrosis factor alpha increases melphalan concentration in tumor tissue after isolated limb perfusion. Br J Cancer. 2000; 82: 1000-3.

13. Rizzel M, Naredi P, Lindner P, Hellstrand K, Sarno M, Jansson PA. Histamine pharmacokinetics in tumor and host tissues after bolus-dose administration in the rat. Life Sci. 2002; 70: 969-76.

\section{Acknowledgements}

We thank Maxim Pharmaceuticals Inc., San Diego, CA for kindly providing Histamine Dihydrochloride injection for the studies

We thank Gerard JJM Borsboom from the Department of Public Health, Erasmus MC, University Medical Center Rotterdam, Rotterdam, the Netherlands for expert assistance with statistical evaluation. 


\section{Correspondence:}

Flavia Brunstein

Rua Fernao Dias 109 - Sao Paulo - SP - Brazil

flis_br@yahoo.com
Conflict of interest: none Financial source: grant from CAPES/MEC - Brazil

Received: March 3, 2005

Revised: April 12, 2005

Aproved: May 17, 2005

\section{How to cite this article:}

Brunstein F, Santos IDAO, Ferreira LM, van Tiel ST, Eggermont AMM, Hagen TLMT. Histamine combined with melphalan in isolated limb perfusion for the treatment of locally advanced soft tissue sarcomas: preclinical studies in rats. Acta Cir Bras [serial online] 2005 Jul-Aug;20(4). Available from: http://www.scielo.br/acb

* Color figures available from http://www.scielo.br/acb

\section{AVISO AOS AUTORES}

Solicita-se aos autores observarem o estilo e as normas da Revista Acta Cirúrgica Brasielira.

Consultar os artigos publicados em fascículos recentes da revista.

Acessar http://www.scielo.br/acb - Instruções aos autores.

Informações adicionais pelo e-mail: sgolden@terra.com.br 